\title{
OBSERVATION OF THE EFFECT ON IMMEDIATE MANDIBULAR IMPLANT-SUPPORTED OVERDENTURE OF MICRO IMPLANT SYSTEM OF ITALY
}

\author{
OBSERVAÇÃO DO EFEITO NA SOBREDENTADURA IMEDIATA MANDIBULAR \\ SUPORTADA POR IMPLANTE DO SISTEMA DE MICRO IMPLANTE DA ITÁLIA
}

\author{
Yin XUEMENG ${ }^{1}$; Dai SHASHA ${ }^{2 *}$ \\ 1. Department of Stomatology, Sir Run Run Hospital, Nanjing Medical University, Nanjing, China. sheharyarharoon@gmail.com; \\ 2. Department of Infectious diseases, Children's Hospital of Nanjing Medical University, Nanjing, China. \\ *(Both authors contributed equally)
}

\begin{abstract}
The study was design to investigate the clinical effect of Micro implant system in Italy on immediate mandibular implant-supported overdenture. A total of 192 patients with mandibular edentulous treated in our hospital were randomly divided into 2 groups in which the control group consisted of 96 patients treated with immediate mandibular implant-supported overdenture by Xive implant system, while the observation group included 96 cases treated with the overdenture by Italy Micro implant system. Patients were followed up for 1 year and then the states of implant-borne overdentures, marginal bone resorption around alveolar bone, the compatibility of implant restorations with adjacent teeth, adverse events and satisfaction degree were compared between the groups. According to the results of 1-year follow-up, the resorption around alveolar bone of the observation group was significantly higher than that of the control group $(p<0.05)$. In the observation group the differences in labial gingival margin position, gingival color and texture were significantly better $(p<0.05)$ as compared to control group. The incidence of adverse events was notably lower $(p<0.05)$. The Italy Micro implant system has significant curative effect on mandibular implant-supported overdentures with good compatibility of the implant restorations with adjacent teeth and low incidence rate of adverse reactions, so it is worthy of clinical application and spreading.
\end{abstract}

KEYWORDS: Italy Micro implant system. Mandibular overdenture. Restoration. Xive system.

\section{INTRODUCTION}

Implant overdenture, usually relying on attachments, provides good support, retention and stability (ELSYAD; ABID; ELKHALEK, 2017) The denture is connected with fixture abutments through different attachments to form readilyremoved implant supported overdentures in patients. The implant supported overdenture is an effective restoration scheme for patients with poor anatomy conditions of mandible jaw as well as deficient retention and stability of traditional complete dentures(ALQUTAIBI; KADDAH; FAROUK, 2017) At present, the project of traditional overdenture in the upper jaw and implant supported overdenture in the lower jaw has become an effective restoration plan for edentulous patients with moderate and severe resorption of alveolar bone, which has been recognized by international dentists(ELANWAR; ELTAFTAZANY; HAMED, 2017; BAHRAMI; ALSHARBATY, 2017).The implant supported overdenture with far lower cost than restoration of the whole dentition is economical, comfortable and effective, leading to the advantages of removable denture as well as good stability of fixed denture after the restoration and thus being welcomed by more and more patients (SHAH; YILMAZ; MCGLUMPHY,2017; ALQUTAIBI, 2016). The Italy B\&B system entitles dental implant to controllable moderate microroughness and shortened time of osseointegration through the surface treatments of alumina sandblasting, double acid etching and argon ion cleansing. There is no domestic report on the application of Italy B\&B implant system to immediate mandibular implant-supported overdentures. Several studies mentioned that by increasing the number of implants, the retention and stability improve, and correspondingly the loading placed on individual implants decrease (KRONSTRÖM; WIDBOM; SODERFELDT, 2006). On the other hand, mandibular over-denture retained by 2 implants has become the first choice of treatment for edentulous individuals due to the decreased treatment cost, and invasiveness of the operation (FITZPATRICK, 2006; ODA et al., 2017). Based on the fact that mandibular canines and premolars are usually the last to be lost, and the most resilient teeth, recommendations have been reported for these teeth on abutment selection, load 
distribution, and support for over-dentures (DOLDER, 1961; MORROW et al., 1969; SCHWARTZ; MORROW, 1996) Moreover, it was reported that the vertical retention and horizontal stability of over-denture increased with distal implant location up to the second premolar (SCHERER et al., 2014). Furthermore, it was reported that progressive residual ridge resorption may affect peri-implant stress distribution. Several studies measured the vertical posterior ridge resorption to range from $0.5 \mathrm{~mm}$ to $1 \mathrm{~mm}$ over 5 years, and $1.4 \mathrm{~mm}-1.5 \mathrm{~mm}$ over 10 years (WRIGHT et al., 2002; KORDATZIS; WRIGHT; MEIJER, 2003; DE JONG et al., 2010). This study aims to investigate application effect of the Italy $B \& B$ planting system so as to provide reference for mandibular overdentures, with the results reported now as follows.

\section{DATA AND METHODS}

\section{General Information}

A total of 192 patients with mandibular edentulous treated in our hospital from July 2015 to May 2016 were selected as the objects. The selected patients were free of diabetes, hypertension, hemorrhagic disorders, severe systemic diseases, compromised immune systems, or history of radiotherapy in the head or neck region. All selected patients signed an informed consent form and were randomly and equally divided into 2 groups: the control group (96 cases) consisting of 61 males and 35 females aged 56 74 with an average age of (63.5 \pm 6.2$)$ years and the observation group (96 cases) consisting of 60 males and 36 females aged $57 \sim 75$ with an average age of $(63.9 \pm 6.7)$ years. There was no significant difference in patient age and sex between the 2 groups ( $p>0.05)$, suggestive of comparability.

\section{METHODS}

The control group was treated with immediate mandibular implant-supported overdenture by Xive implant system while the observation group by Italy Micro implants system produced by Micro implant system Via San Benedetto, San Pietro in Casale (BO), Italy. The basic ZC-J type hydroxyapatite produced by Beijing Yihua Technology \& Trade Co., Ltd. and the C type Haiao dental prostheses manufactured by Yantai Zhenghai Biological Technology Co. Ltd. were adopted for bone grafting. Digital panorama photographing was performed before operation in patients to measure the height and width of the implant, estimate the bone density and select the appropriate implant model.

\section{Surgical procedures}

The surgery was performed under Local Anesthesia (Lidocaine 2\% containing 1: 100,000 epinephrine). The surgical guide was kept in place by firm finger compression until local anesthesia was administered through the sleeves of the anchor pins, and the guide then was stabilized by placement of the anchor pins. Figure 1. A tissue punch was then used to remove the gingival tissue under the implant sleeves. Drilling protocol was then followed for each osteotomy site according to the drill sequence. The drilling depth was controlled by a drill stop on the shank that corresponded to the sum of the implant length, the gap between the guiding sleeve and the implant, and the guiding sleeve height. Xive implant system and Italy B\&B implant system (B\&B Dental Implant Company via San Benedetto, San Pietro in Casale (BO), Italy.) were then placed for patients of group A and group B correspondingly with insertion torque of at least 35 $\mathrm{Nm}$. The guide was then removed and the cover screws were placed as shown in figure 2 .

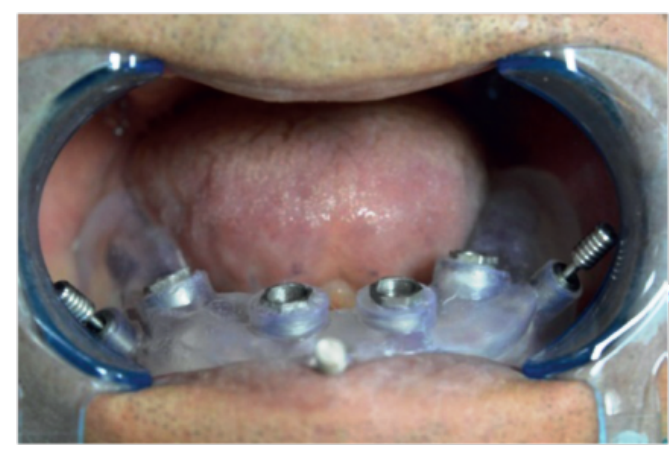

Figure 1. The surgical guide stabilized intra-oral with the anchor pins 


\section{Post-surgical instructions}

Patients were instructed to wear their dentures immediately to minimize postoperative swelling and removed only for cleaning. Postoperatively, antibiotics (amoxicillin and clavulanic acid $625 \mathrm{mg}$ three times a day) for 7 days and non- steroidal analgesics (Ibuprofen $400 \mathrm{mg}$ three times daily) were prescribed. Patients are instructed to rinse with Chlorhexidine Gluconate Oral Rinse $0.12 \% 3$ times per day for 2 weeks. Patients were recalled for follow-up observation and adjustment period of 4 months.

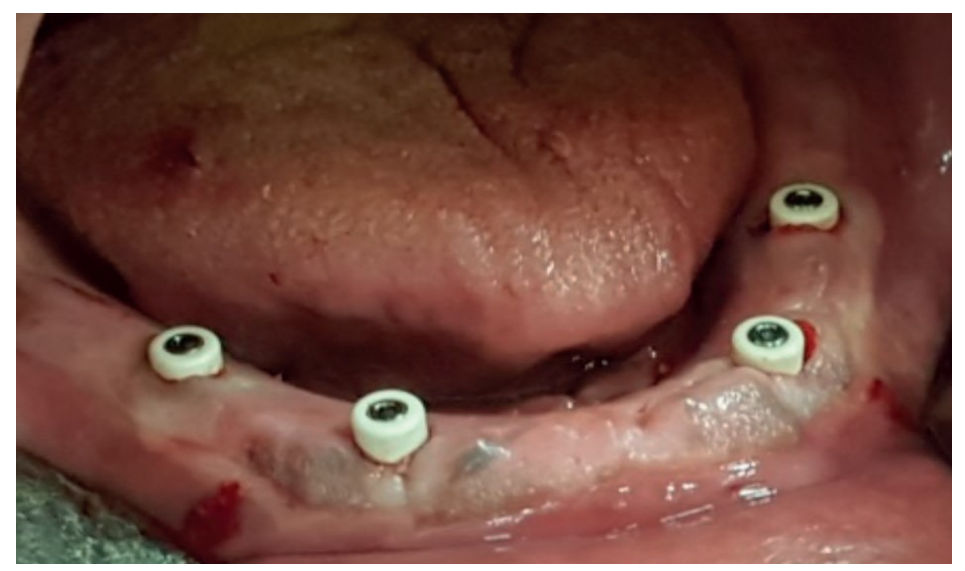

Figure 2. Intra-oral image showing implants with healing abutments

\section{Prosthetic procedure}

Three weeks postoperatively, the patient's existing mandibular dentures were relieved over implant sites and refitted to the mucosa using a tissue conditioner. After 4 months of healing, implants healing abutments were placed. Fig (3a) complete denture was then connected to the implants with Locator attachment abutments using the direct pick-up technique. The locator attachment consisted of: Locator abutment (The female component, medium (M), gingival height $3 \mathrm{~mm}$ ), Locator matrix (metal base with inner retention male insert, attached to the fitting surface of the over-denture), Locator black processing insert, and Retention male inserts (nylon inserts, fitted to the locator matrix, available in different colors according to the degree of retention). The used insert in this study was pink (medium retention; $1.365 \mathrm{~g}$ ). For both groups, abutments were screwed into the implant hex using a $35 \mathrm{Ncm}$ torque. The fitting surface of the new mandibular dentures directly above the implants was hollowed out to provide space for the attachments. The outer matrices for both groups were picked up intraorally to the fitting surface of mandibular dentures with cold-cure acrylic resin while the patients hold maxillary and mandibular dentures in centric occlusion. Figures 3a, 3b. The locator black processing inserts were removed and pink nylon inserts were fitted to the locator matrix. The occlusion was refined before using the denture.

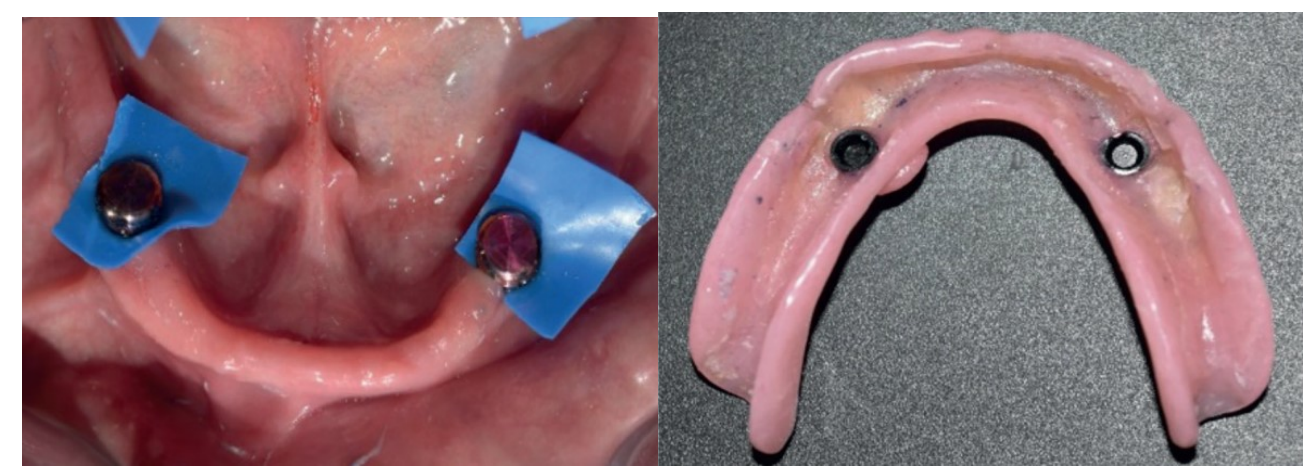

Figure 3. (A) Intra-oral image showing blocking the undercuts for pickup impression (B) image showing nylon cap and metal housing related to the fitting surface of the over-denture

\section{Observation Index}

The states of dental implantation and restoration, the resorption around alveolar bone, the differences in labial gingival margin position, gingival color and texture, the incidence of adverse 
events as well as the satisfaction degree by 1-year follow up was observed.

\section{Evaluation criteria}

\section{Assessment Standard for Dental Implantation State}

Successful implantation: the implant was fixed well with no adverse events such as periodontal inflammation and local pain seen in patients. Unsuccessful implantation: the implant had poor fixation with periodontal inflammation or local pain in patients, who cannot be repaired because of falling into the upper jaw or too large angle, or there was fracture of implant and connector.

\section{Assessment Criteria for Restoration}

Successful restoration: there was no loosening or breakage; Unsuccessful restoration: there was loosening of the central screw in the fixed implant or abutment.

\section{Evaluation Criteria for the Difference of Labial Gingival Margin Position}

No difference: the difference of labial gingival margin was less than $1 \mathrm{~mm}$; slight difference: the difference of labial gingival margin was $1 \sim 2 \mathrm{~mm}$; obvious difference: the difference of labial gingival margin was more than $2 \mathrm{~mm}$.

\section{Evaluation Standard of the Differences in Gingival Color and Texture}

The differences in gingival color and texture were evaluated according to the standards of the Dental Aesthetic Index (DAI) survey by Furhauser, including such 7 indexes as mesial papillae gingiva, distal papillae gingiva, labial gingival margin level, soft tissue shape, dental process contour as well as soft tissue color and texture. The score of 13 14 suggested no difference, $8 \sim 12$ slight difference and $0 \sim 7$ obvious difference.

\section{Assessment criteria for patient satisfaction}

The satisfaction degree in patients was assessed by self-made questionnaire, including following three levels: very satisfied, satisfied and dissatisfied, which was evaluated by the patients according to their own feelings with the sum of very satisfied and basically satisfied levels as total satisfaction.

\section{Statistical methods}

SPSS 21 software was used to analyze the data, the measurement data were expressed by mean \pm standard deviation and checked by $t$ test, and the enumeration data were expressed by rate (\%) and checked by chi square test, $p<0.05$ suggested that there was statistically significant difference between the groups.

\section{Ethics Committee Approval}

This study was certified by the Ethics Committee of the Department of Stomatology, Sir Run Run Hospital, Nanjing Medical University. Nanjing, 211000, China. All patients signed the informed consent in this research and it was conducted as per Helsinki's declaration for human volunteers.

\section{RESULTS}

\section{Comparison of Implantation and Restoration of Mandibular Denture Deletion between the Two Groups}

The successful rates of dental implantation and restoration were respectively $99 \%$ and $98 \%$ in the observation group, significantly higher than those in the control group $(p<0.05)$, as shown in table 1 .

Table 1. Comparison of implantation and restoration of mandibular denture deletion between the two groups [n $(\%)]$

\begin{tabular}{lllllr}
\hline \multirow{2}{*}{ Group } & $\mathrm{N}$ & \multicolumn{3}{l}{ implantation status } & restoration status \\
\cline { 3 - 6 } & & Successful & Unsuccessful & successful & unsuccessful \\
control group & 96 & $87(90.6)$ & $9(9.4)$ & $86(89.6)$ & $10(10.4)$ \\
observation & 96 & $95(99)$ & $1(1)$ & $87(98)$ & $2(2)$ \\
group & & 6.944 & & 7.125 & \\
$\mathrm{X}^{2}$ & & $<0.05$ & & $<0.05$ & \\
$\mathrm{P}$ & & & & \\
\hline
\end{tabular}




\section{Comparison of the Resorption around Alveolar Bone between the 2 Groups after 1-Year Follow- Up}

After 1-year follow-up, the resorption around alveolar bone was $0.08 \sim 0.65(0.41 \pm 0.07)$ $\mathrm{mm}$ in the observation group and $0.29 \sim 0.18$ $(0.11 \pm 0.04) \mathrm{mm}$ in the control group with no statistically significant difference between the 2 groups $\left(\mathrm{X}^{2}=9.152, \mathrm{P}<0.05\right)$.

\section{Comparison of the Compatibility of Implant Restorations with Adjacent Teeth between the 2 Groups after 1-Year Follow-Up}

After 1-year follow-up, the differences in labial gingival margin position, gingival color and texture were significantly better in the observation group than in the control group $(\mathrm{P}<0.05)$, as shown in table 2.

Table 2. Comparison of the compatibility of implant restorations with adjacent teeth between the 2 groups after 1 -year follow-up (\%)

\begin{tabular}{|c|c|c|c|c|c|c|c|}
\hline \multirow{2}{*}{ Group } & \multirow{2}{*}{$\mathrm{N}$} & \multicolumn{3}{|c|}{$\begin{array}{l}\text { the difference in labial gingival margin } \\
\text { position }\end{array}$} & \multicolumn{3}{|c|}{$\begin{array}{l}\text { the difference in gingival color and } \\
\text { texture }\end{array}$} \\
\hline & & $\begin{array}{l}\text { no } \\
\text { difference }\end{array}$ & $\begin{array}{l}\text { slight } \\
\text { difference }\end{array}$ & $\begin{array}{l}\text { Obvious } \\
\text { difference }\end{array}$ & $\begin{array}{l}\text { no } \\
\text { difference }\end{array}$ & $\begin{array}{l}\text { slight } \\
\text { difference }\end{array}$ & $\begin{array}{l}\text { obvious } \\
\text { difference }\end{array}$ \\
\hline $\begin{array}{l}\text { control } \\
\text { group }\end{array}$ & 96 & $73(76)$ & $21(21.9)$ & $2(2.1)$ & $76(79.2)$ & $19(19.8)$ & $1(1)$ \\
\hline $\begin{array}{l}\text { observation } \\
\text { group }\end{array}$ & 96 & 94 (97.9) & $2(2.1)$ & $0(0)$ & 95 (99) & $1(1)$ & $0(0)$ \\
\hline & & 7.443 & & & 8.062 & & \\
\hline $\mathrm{P}$ & & $<0.05$ & & & $<0.05$ & & \\
\hline
\end{tabular}

\section{Comparison of Adverse Events between the 2 Groups}

The incidence of adverse events in the observation group was $3.1 \%$, which was significantly lower than that in the control group (P $<0.05)$, as shown in table 3 .

Table 3. Comparison of adverse events between the 2 groups (\%)

\begin{tabular}{llllllll}
\hline Group & $\mathrm{N}$ & $\begin{array}{l}\text { abutment } \\
\text { looseness }\end{array}$ & $\begin{array}{l}\text { abutment } \\
\text { fracture }\end{array}$ & $\begin{array}{l}\text { center } \\
\text { screw } \\
\text { looseness }\end{array}$ & $\begin{array}{l}\text { center } \\
\text { screw } \\
\text { fracture }\end{array}$ & periimplantitis & sum \\
control group & 96 & $4(4.2)$ & $2(2.1)$ & $4(4.2)$ & $2(2.1)$ & $9(9.4)$ & $21(21.9)$ \\
observation group & 96 & $0(0)$ & $0(0)$ & $1(1)$ & $0(0)$ & $2(2.1)$ & $3(3.1)$ \\
$X^{2}$ & & & & & & & 9.076 \\
P & & & & & & $<0.05$
\end{tabular}

\section{Comparison of Satisfaction Degree between the 2 Groups}

The satisfaction degree of patients in the observation group was $97.9 \%$, which was significantly higher than that in the control group, that was $88.5 \%(\mathrm{P}<0.05)$, as shown in table 4 .

Table 4. Comparison of satisfaction degree between the 2 groups (\%)

\begin{tabular}{cccccc}
\hline Group & $\mathrm{N}$ & very satisfied & satisfied & dissatisfied & total satisfaction \\
\hline control group & 96 & $73(76)$ & $12(12.5)$ & $11(11.5)$ & $85(88.5)$ \\
observation group & 96 & $90(93.8)$ & $4(4.2)$ & $2(2.1)$ & $94(97.9)$ \\
$\mathrm{X}^{2}$ & & & & 7.023 \\
$\mathrm{P}$ & & & & $<0.05$
\end{tabular}

The achievement ratio of dental implantation, the successful rate of restoration and satisfaction degree in patients were significantly higher in the observation group than in the control groups $(\mathrm{P}<0.05)$; according to the results of 1-year follow-up, the resorption around alveolar bone of the observation group was significantly higher than that of the control group $(\mathrm{p}<0.05)$; compared with 
the control group, in the observation group the differences in labial gingival margin position, gingival color and texture were significantly better $(\mathrm{p}<0.05)$ and the incidence of adverse events was notably lower $(p<0.05)$. These suggest that the Italy Micro implant system has significant curative effect on mandibular implant-supported overdentures with high success rates of implant and restoration, leading to good marginal absorption around alveolar bone after operation, good compatibility of the implant restorations with adjacent teeth and low incidence rate of adverse reactions, thus worthy of clinical application and spreading.

\section{DISCUSSION}

With the development of population aging, the weakening of body function and the change of diet structure, the elderly are susceptible to developing edentulous jaws. Tooth loss leads to the failure of tooth chewing effect in patients, which affects the effect of mouth on preliminary digestion of food, increases gastrointestinal burden and meanwhile exerts impacts on patient vocal function, especially on dental and labiodental sounds (ZHENG; LI; LIAO, 2017; MANKOO, 2007). Because the tooth fails to maintain 1/ 3 lower faces and support lip and cheek soft tissue, patients begin to have old facial features with shorter lower surface, soft tissue collapse, deepened wrinkles and drooping mouth. With the elapse of time, the alveolar ridge, oral mucosa, temporomandibular joint and muscle nerves of edentulous patients will undergo further degenerative and pathological changes (MOEN; KVALVIK; HELLEM, 2005; TAIWO; KOLUDE; AKINMOLADUN， 2009; BORUMANDI; BÜRGER; GAGGL, 2013). These changes will affect the patients' psychological status and even social activities, so it is required to restore related functions as soon as possible.

At present, the effective method for the clinical treatment of dentition defect is implantsupported restoration (ZHOU; LIU; LIANG, 2008). The placement of implants in the alveolar ridge enables to provide different extent of retention, stabilization and support for the denture according to the number of implant, giving rise to different repair effects. When 1 2 implants are adopted in patients with single edentulous jaw, the implant can connect with the overdenture by means of some devices such as magnetic attachment, bar clip attachment and ball-cap attachment, which mainly provides the effects of stability and retention with several supports; when 4 implants are adopted in this case, a large part of support force can be borne by the implant; when more than 4 implants are used, the support, retention and stability of the denture may be entirely maintained by the implant, even leading to complete dentures supported by implants (MACHADO; CHACON; SÁNCHEZ, 2008; SADIG, 2009). At present, some developed countries have extended mandibular complete dentures supported by 2 implants as the routine restoration method for dentition defect (ARAFA, 2016).

On the other hand, Talawy et al and Elawady et al. (2016) have shown lesser marginal bone resorption with single implant compared with 2-implant supported overdenture. Moreover, it was reported by Helmy et al that the assessment of periimplant radiographic marginal bone loss cannot be recommended as a parameter to evaluate the effectiveness of oral implants. It should be only a measure of the disease process, and for the early detection of potential problems. Furthermore, the controversies regarding marginal bone loss could be attributed to lack of the standardization in methods used for the evaluation. Periapical radiographs and CBCTs are reported to be acceptable in measuring peri-implant bone levels (LILJEHOLM et el., 2017; SHEREEN; INGY; AHMED, 2017) Also, it is difficult to correctly measure marginal bone loss in values less than $1 \mathrm{~mm}$ on panoramic X-rays. Thus the record of the current study was taken on CBCT for its accuracy as supported and used by several studies. (MAGGIE; SHEREEN, 2014; MAGGIE; SHEREEN, 2017; LIU et al., 2013)

Micro implant system is one of the most famous brands in Italy with a very high reputation in Europe. Its product is of universal design, relatively simple structure and unique surface coasting, which on the one hand ensures stable connection of the implant with the alveolar bone in patients, and on the other hand can prevent bacterial invasion to the inside implant, leading to good durability. Besides, a lot of work has been done on optimum designs of the Italy Micro implant system for the elderly, especially suitable for people with all kinds of poor alveolar bone. The system has extremely reliable effect of dental restoration, contributing to the submucosal and mucosal healing, and the implant can be loaded immediately after successful implantation with resin-bonded fixed effect, the restored tooth supported by implant is still very good-looking and the surrounding soft tissues are stable with no inflammatory infiltration, ensuring high safety and operability. The Italy Micro implant system has good biocompatibility and bone binding capability, providing great range of choice with 
wide application scopes. The anatomy of the implant is similar to that of the natural root and the amount of bone grafting can be largely narrowed in the course of immediate implant. This finding corresponds to the finding of other studies (DEUKWON et al., 2015; WARINA et al., 2018).

\section{Limitations of the study}

When a dental implant needs to go into a narrow edentulous space, a $3.0 \mathrm{~mm}$ implant might be the perfect solution. However, there are limitations to these implants.

The first and perhaps most important limitation is that all $3.0 \mathrm{~mm}$ implants on the market are only indicated for maxillary lateral incisors and mandibular central and lateral incisors. Placing a $3.0 \mathrm{~mm}$ implant in any other position may void the implant warranty.

Some manufacturers restrict $3.0 \mathrm{~mm}$ implants to non-splinted single units

$>\quad$ Finally, the $3.0 \mathrm{~mm}$ implants offer a smaller selection of restorative components

\section{Futuristic Reports}

The growth and development of Global Dental Mini-Implant Market Report 2020 by Players, Regions, Type, and Application, forecast to 2026 provides industry analysis and forecast from 2020-2026. Global Dental Mini-Implant Market analysis delivers important insights and provides a competitive and useful advantage to the pursuers. Dental Mini-Implant processes, economic growth is analyzed as well. The data chart is also backed up by using statistical tools.

Simultaneously, we classify different Dental Mini-Implant markets based on their definitions.
Downstream consumers and upstream materials scrutiny are also carried out. Each segment includes an in-depth explanation of the factors that are useful to drive and restrain it.

\section{CONCLUSION}

The results of this study showed that compared with the immediate mandibular implant supported overdenture by Xive implant system, the overdenture by Micro implant system has significantly higher success rates of implantation and restoration. And according to 1-year follow-up, the Italy Micro implant system is more effective in immediate overdentures, leading to more marginal bone resorption of alveolar bone, small differences in labial margin position and gingival color and texture as well as less adverse events such as abutment loosening and fracture, central screw loosening and fracture and peri-implant mucositis. These suggest that the Italy Micro implant system has significant effects on mandibular implantsupported overdentures with high success rates of implant and restoration, good marginal absorption around alveolar bone after operation, good compatibility of the implant restorations with adjacent teeth and low incidence rate of adverse reactions, thus worthy of clinical application and spreading.

\section{ACKNOWLEDGMENTS}

Thanks for the Department of Stomatology for providing facilities to conduct this research work.

RESUMO: O estudo foi desenvolvido para investigar o efeito clínico do sistema de implantes de B\&B na Itália na prótese total imediata apoiada em implante mandibular. Um total de 192 pacientes com desdentação mandibular, tratados em nosso hospital foram divididos aleatoriamente em 2 grupos, nos quais o grupo controle consistia em 96 pacientes tratados com overdenture imediato apoiado por implante mandibular pelo sistema de implante Xive, enquanto o grupo de observação incluiu 96 casos tratados com o sobredentadura pelo sistema de implantes Itália B\&B. Os pacientes foram acompanhados por 1 ano e, em seguida, foram comparados os estados de sobredentaduras implanto-suportadas, reabsorção óssea marginal ao redor do osso alveolar, compatibilidade das restaurações do implante com dentes adjacentes, eventos adversos e grau de satisfação. De acordo com os resultados do seguimento de 1 ano, a reabsorção ao redor do osso alveolar do grupo de observação foi significativamente maior que a do grupo controle $(p<0,05)$. No grupo de observação, as diferenças na posição da margem gengival labial, cor gengival e textura foram significativamente melhores ( $p$ $<0,05)$ em comparação ao grupo controle. A incidência de eventos adversos foi notavelmente menor $(\mathrm{p}<0,05)$. O sistema de implantes B\&B da Itália tem um efeito curativo significativo nas sobredentaduras mandibulares suportadas por implantes, com boa compatibilidade das restaurações dos implantes com dentes adjacentes e baixa taxa de incidência de reações adversas, por isso é digno de aplicação clínica e disseminação. 
PALAVRAS-CHAVE: Overdenture mandibular. Sistema de micro-implantes na Itália. Sistema Xive. Restauração.

\section{REFERENCES}

ALQUTAIBI, A. Y. Limited Evidence Suggests a Single Implant Overdenture as an Alternative to Twoimplant-Supported Mandibular Overdentures. The Journal Of Evidence-Based Dental Practice, v. 16, n. 1, p. 44-6. 2016. https://doi.org/10.1016/j.jebdp.2016.01.009

ALQUTAIBI, A. Y.; KADDAH, A. F.; FAROUK, M. Randomized study on the effect of single-implant versus two-implant retained overdentures on implant loss and muscle activity: a 12-month follow-up report.

International Journal of Oral \& Maxillofacial Surgery, v. 46, n. 6, p. 789-797, 2017.

https://doi.org/10.1016/j.ijom.2017.02.001

ARAFA, K. A. The impact on bone tissues of immediate implant-supported mandibular overdentures with cusped and cuspless teeth. Saudi Medical Journal, KSA, v. 37, n. 1, p. 79-83, 2016.

https://doi.org/10.15537/smj.2016.1.12097

BAHRAMI, M.; ALSHARBATY, M. H. Using individual two-posterior short implants with two-anterior standard implants in mandibular implant-supported-overdenture to enhance the patient satisfaction: A clinical report. Dental Hypotheses, v. 8, n. 2, p. 48, 2017 https://doi.org/10.4103/2155-8213.206104

BORUMANDI, F.; BÜRGER, H.; GAGGL, A. Combined second metatarsophalangeal joint and extended dorsalis pedis flap for reconstruction of temporomandibular joint and oral mucosa. British Journal of Oral \& Maxillofacial Surgery, v. 51, n. 4, p. 54-6, 2013. https://doi.org/10.1016/j.bjoms.2012.03.011

DE JONG, M. H.; WRIGHT, P. S.; MEIJER, H. J.; TYMSTRA, N. Posterior mandibular residual ridge resorption in patients with overdentures supported by two or four endosseous implants in a 10-year prospective comparative study. International Journal of Oral and Maxillofacial Implants; v. 25, p. 1168-74, 2010. https://doi.org/10.15713/ins.idmjar.69

DEUK-WON JO, D.D.S, P.H.D.A AND JIN-KEUN DONG. Effects of posterior ridge resorption and attachment wear on periimplant strain in mandibular two-implant-supported overdentures. The Journal of Prosthetic Dentistry, v. 114, p. 839-847, 2015. https://doi.org/10.1016/j.prosdent.2015.06.011

DOLDER, E. J. The Bar Joint Mandibular Denture. The Journal of Prosthetic Dentistry, v. 11, p. 689-707, 1961. https://doi.org/10.1016/0022-3913 (61)90178-0.

ELANWAR, M. I.; ELTAFTAZANY, E. A.; HAMED, H. A. Influence of Number of Implants and Attachment Type on Stress Distribution in Mandibular Implant-Retained Overdentures: Finite Element Analysis. Open Access Macedonian Journal of Medical Sciences, v. 5, n. 2, p. 244-249, 2017. https://doi.org/10.3889/oamjms.2017.047 eISSN: 1857-9655.

ELAWADY, D. M.; KADDAH, A.; OMAR, H.; NABY, N. A. Impact of single versus two implants on the bone height loss and bone density for patients restored by implant-retained mandibular overdentures. The European Journal of Dentistry, v. 62, p. 2849-56, 2016. https://doi.org/10.21608/edj.2019.72176

ELSYAD, M. A.; ABID, K. S.; ELKHALEK, E. A. Effect of Buccal Implant Inclination on Stresses Around Two-Implant-Retained Overdentures with Resilient Stud Attachments. International Journal of Oral \& Maxillofacial Implants, v. 32, n. 3, 2017. e135-e142. https://doi.org/10.11607/jomi.5427. Epub 2017 Apr 12

FITZPATRICK, B. Standard of care for the edentulous mandible: a systematic review. Journal of Prosthetic Dentistry, v. 95, n. 71, 2006. https://doi.org/10.1016/j.prosdent.2005.11.007 
KORDATZIS, K.; WRIGHT, P. S.; MEIJER, H. J. Posterior mandibular residual ridge resorption in patients with conventional dentures and implant over-dentures. International Journal of Oral \& Maxillofacial Implants, v. 18, p. 447-52, 2003. https://doi.org/10.1016/j.prosdent.2003.08.016

KRONSTRÖM, M.; WIDBOM, C.; SODERFELDT, B. Patient evaluation after treatment with maxillary implant-supported overdentures. Clinical Implant Dentistry and Related Research, v. 8, p. 39-43, 2006. https://doi.org/10.2310/j.6480.2005.00029.x

LILJEHOLM, R.; KADESJÖ, N.; BENCHIMOL, D.; HELLÉN-HALME, K.; SHI, X. Q. Cone-beam computed tomography with ultralow dose protocols for pre-implant radio-graphic assessment: an in vitro study. European journal of oral implantology, v. 10, p. 351-9, 2017.

LIU, J.; PAN, S.; DONG, J.; MO, Z.; FAN, Y.; FENG, H. Influence of implant number on the biomechanical behaviour of mandibular implant-retained/supported overdentures: a three-dimensional finite element analysis. Journal of Dentistry, Netherlands, v. 41, p. 241-9, 2013. https://doi.org/10.1016/j.jdent.2012.11.008. Epub 2012 Nov 14.

M. H. E.D, HELMY, A. Y. ALQUTAIBI, A. A. EL-ELLA, A. F. SHAWKY: Effect of implant loading protocols on failure and marginal bone loss with unsplinted two-implant supported mandibular over-dentures: systematic review and metaanalysis. International Journal of Oral and Maxillofacial Surgery, v. 47, p. 642650, 2018. https://doi.org/10.1016/j.ijom.2018.10.018

MACHADO, C.; CHACON, G.; SÁNCHEZ, E. Palatal mini-implants to increase retention and stability of implant-retained maxillary overdentures: a case report. Implant Dentistry, v. 17, n. 4, 402-7, 2008.

https://doi.org/10.1097/ID.0b013e31818c49d0

MAGGIE, A. K.; SHEREEN, W. Arafat. Buccal bone remodeling after immediate implant placement with and without grafting. Uropean Journal of Dentistry, v. 60, p. 4913-21, 2014.

MAGGIE, A. K.; SHEREEN, W. ARAFAT. Restoration of the peri-implant defect of immediate Implant by bovinederived xenograft with and without PRFE. Uropean Journal of Dentistry, v. 60, p. 2017-34, 2014.

MANKOO, T. Single-tooth implant restorations in the esthetic zone--contemporary concepts for optimization and maintenance of soft tissue esthetics in the replacement of failing teeth in compromised sites. The European Journal of Esthetic Dentistry, v. 2, n. 3, p. 274-295, 2007. PMID: 19655551.

MOEN, K.; KVALVIK, A. G.; HELLEM, S. The long-term effect of anti TNF- $\alpha$ treatment on temporomandibular joints, oral mucosa, and salivary flow in patients with active rheumatoid arthritis: A pilot study. Oral Surgery Oral Medicine Oral Pathology Oral Radiology \& Endodontics, v. 100, n. 4, p. 433440, 2005. https://doi.org/10.1016/j.tripleo.2005.05.060

MORROW, R. M.; FELDMANN, E. E.; RUDD, K. D.; TROVILLION, H. M. Tooth-supported complete dentures: an approach to preventive prosthodontics. Journal of Prosthetic Dentistry, v. 21, p. 513-22, 1969. https://doi.org/10.1016/0022-3913(69)90073-0

ODA, K.; KANAZAWA, M.; TAKESHITA, S.; MINAKUCHI, S. Influence of implant number on the movement of mandibular implant over-dentures. Journal of Prosthetic Dentistry, v. 117, p. 380-385, 2017. https://doi.org/10.1016/j.prosdent.2016.08.005. Epub 2016 Sep 24.

SADIG, W. A comparative in vitro study on the retention and stability of implant-supported overdentures.

Quintessence International, v. 40, n. 4, p. 313-319. 2009. https://www.ncbi.nlm.nih.gov/pubmed/19417876.

SCHERER, M. D.; MCGLUMPHY, E. A.; SEGHI, R. R.; CAMPAGNI, W. V. Comparison of retention and stability of two implant-retained over-dentures based on implant location. Journal of Prosthetic Dentistry, p. 112, p. 515-521, 2014. https://doi.org/10.1016/j.prosdent.2014.03.003 .Epub 2014 May 10. 
SCHWARTZ, I. S.; MORROW, R. M. Over-dentures. Principles and procedures. Dental Clinics of North America, v. 40, p. 169-94, 1996. https://doi.org/10.1016/j.cden.2004.03.002

SHAH, K.; YILMAZ, B.; MCGLUMPHY, E. Fabrication of a Mandibular Implant-Supported Overdenture with a New Attachment System: A Review of Current Attachment Systems. International Journal of Prosthodontics, v. 30, n. 3, p. 245-247, 2017. https://doi.org/10.11607/ijp.5068. Epub 2017 Mar 20.

SHEREEN W ARAFAT, INGY M CHEHATA, AHMED M HOSSAM. Sinus floor augmentation with simultaneous implant placement using Bio-Oss with and without PRF: Clinical study. European Journal of Dentistry, v. 63, p. 151-160, 2017. https://doi.org/10.21608/edj.2017.74752

TAIWO, J. O.; KOLUDE, B.; AKINMOLADUN, V. Oral mucosal lesions and temporomandibular joint impairment of elderly people in the South East Local Government Area of Ibadan. Gerodontology, v. 26, n. 3, p. 219-224, 2009. https://doi.org/10.1111/j.1741-2358.2008.00249.x

WARINA, P.; RUNGSIYAKULLB, P.; RUNGSIYAKULLC, C.; KHONGKHUNTHIAND, P. Effects of different numbers of mini-dental implants on alveolar ridge strain distribution under mandibular implantretained overdentures. Journal of Prosthodontic Research, v. 62, p. 35-43, 2018.

https://doi.org/10.1016/j.jpor.2017.05.002. Epub 2017 Jul 29.

WRIGHT, P. S.; GLANTZ, P. O.; RANDOW, K.; WATSON, R. M. The effects of fixed and removable implant-stabilized prostheses on posterior mandibular residual ridge resorption. Clinical Oral Implants Research, v. 13, p. 169-74, 2002. https://doi.org/10.1034/j.1600-0501.2002.130207.x

ZHENG, K.; LI, Z.; LIAO, W. Friction and wear performance on ultrasonic vibration assisted grinding dental zirconia ceramics against natural tooth. Journal of the Brazilian Society of Mechanical Sciences \& Engineering, v. 39, n. 3, p. 833-843, 2017. https://doi.org/10.1007/s40430-016-0531-9

ZHOU, G, L.; LIU, D.; LIANG, X. A clinical observation of therapeutic alliance of orthodontics and implant prosthodontics for dentition defect with malocclusion. West China Journal of Stomatology, v. 26, n. 5, p. 499-502, 2008. PMID: 19007069. 